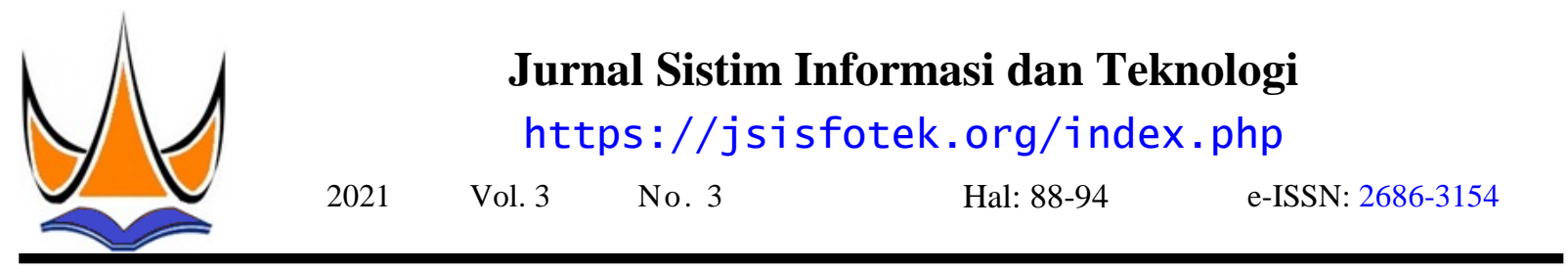

\title{
Prediksi Tingkat Kepuasan dalam Pembelajaran Daring Menggunakan Algoritma Naïve Bayes
}

\author{
Abdi Rahim Damanik ${ }^{1 凶}$, Sumijan $^{2}$, Gunadi Widi Nurcahyo ${ }^{3}$ \\ ${ }^{1}$ AMIK-STIKOM Tunas Bangsa \\ ${ }^{2,3}$ Universitas Putra Indonesia YPTK Padang \\ abdirahimdmk@gmai 1.com
}

\begin{abstract}
The growth of learning at this time is influenced by advances in data and communication technology. One of the data technologies that functioned in the world of learning during the COVID-19 pandemic was online education. Online education is used as a liaison between lecturers and students in an internet network that can be accessed at any time. The online media used are Whatsapp, Google Classroom, Google Meet, Cloud x and the Zoom application. This research aims to predict the level of student satisfaction in online education as well as to distribute donations to large academies in making policies related to improving the quality of education online. The information used was obtained by distributing questionnaires to 110 students of the 2020/2021 class. The parameters in the questionnaire are lecturer communication, online education atmosphere, student evaluation, module delivery. Naïve Bayes is a prediction method for finding simple probabilities based on the Bayes theorem with a strong assumption of independence. Rapid Miner is one of the tools used for testing information and viewing the results of accuracy based on revolutionary information. The results of the test using 80 training information and 30 testing information show very good accuracy.
\end{abstract}

Keywords: Online Learning, Naïve Bayes, Prediction, Satisfaction Level, Covid 19.

\begin{abstract}
Abstrak
Pertumbuhan pembelajaran pada saaat ini dipengaruhi oleh kemajuan teknologi data serta komunikasi. Salah satu teknologi data yang berfungsi dalam dunia pembelajaran pada masa pandemi COVID-19 yaitu pendidikan secara daring. Pendidikan daring digunakan selaku penghubung dosen dengan mahasiswa dalam satu jaringan internet yang bias diakses kapan saja. Media daring yang digunakan ialah Whatsapp, Google Classroom, Google Meet, Cloud x serta aplikasi Zoom. Riset ini bertujuan buat memprediksi tingkatan kepuasan mahasiswa dalam pendidikan daring serta membagikan donasi pada akademi besar dalam mengambil kebijakan yang berhubungan dengan kenaikan mutu pendidikan secara daring. Informasi yang digunakan diperoleh dengan membagikan kuesioner kepada mahasiswaangkatan 2020/2021 sebanyak 110 mahasiswa. Parameter yang ada pada kuesioner ialah komunikasi dosen, atmosfer pendidikan daring, evaluasi terhadap mahasiswa, penyampaian modul. Naïve Bayes ialah salah satu metode prediksi buat mencari probabilitas simple bersumber pada teorema bayes dengan anggapan independensi yang kokoh. Rapid Miner adalah salah satu tools yang digunakan buat pengujian informasi serta memandang hasil akurasi bersumber pada informasi keusioner. Hasil dari pengujian dengan memakai 80 informasi training serta 30 informasi testing menampilkan akurasi yang sangat baik.
\end{abstract}

Kata kunci: Pembelajaran Daring, Naïve Bayes, Prediksi, Tingkat Kepuasan, Covid 19.

(c) 2021 JSisfotek

\section{Pendahuluan}

Pembelajaran secara daring merupakan solusi terbaik terhadap kegiatan belajar mengajar di tengah pandemi COVID-19. Model Pendidikan ini bertujuan untukpeningkatan akses untuk mahasiswa agar mendapatkan pendidikan yang lebih baik serta bermutu [1]. Pembelajaran daring akan memberikan kesempatan bagi mahasiswa untuk dapat mengikuti suatu pembelajaran atau mata kuliah tertentu tanpa harus melaksanakan tatap muka langsung. Dengan menggunakan media pembelajaran daring yaitu

Whatsapp, Google Meet, Cloud $x$ dan Zoom Meeting. Pada penelitian ini penulis akan memprediksi tingkat Perguruan tinggi mengharapkan mahasiswa dapat kepuasan terhadap pembelajaran daring menggunakan mengikuti pendidikan secara efektifserta mendapatkan Algoritma Data Mining metode Naïve Bayes. Data ilmu yang telah diberikan oleh dosen pengajar [2]. yang akan digunakan dengan memberikan kuesioner Pilihan melakukan pembelajaran secara daring kepada mahasiswa angkatan 2020/2021. Dalam memerlukan kesiapan perangkat dan paket data internet penelitian ini terdapat 4 Parameter yaitu Komunikasi, yang masih dikelola secara mandiri. Pemanfaatan Susana Pembelajaran, Penilaian Mahasiswa dan teknologi informasi dalam pembelajaran tidak hanya Penyampaian Materi. 
Tujuan pada penelitian ini yaitu memahami dan data sebanyak 2000 dengan 1661 tweet terklasifikasi mengetahui proses pelayanan pembelajaran secara dan 339 tweet tidak terklasifikasi. Hasil akurasi yang daring serta analisa data tingkat kepuasan didapatkan sebesar $77 \%$ dengan waktu proses 23 detik mahasiswa.Merancang model yang dihasilkan dari [10]. Penelitian mengenai klasifikasi Naïve Bayes algoritma Naïve Bayes dan mengimplementasikan untuk memprediksi partisipasi pemilihan gubernur dan toolsRapidMiner 5.3 kepada bagian Lembaga vokasi gubernur di desa jemirahan kabupaten jahon Penjaminan Mutu. Menguji proses analisa prediksi dengan data yang diambil sebanyak 300 data.Hasil tingkat kepuasan dan tingkat akurasi yang didapat prediksi partisipasi dari data yang diambil adalah 300 menggunakan tools yang sudah ada.

Manfaat penelitian ini yaitu membantu pihak lembaga penjamian mutu dalam menghasilkan informasi yang baru mengenai kepuasan mahasiswa menggunakan algoritma Naïve Bayes serta membantu pihak perguruan tinggi untuk menentukan kebijakan dalam peningkatan kualitas pembelajaran secara daring.

Pada penelitian terdahulumetode Naïve Bayes digunakan untuk memprediksi service ringan, sedang ataupun service berat. Data yang diperoleh adalah data sekunder sebanyak 150 data dan yang digunakan sebanyak 50 data. Hasil dari kegiatan mining ini diharapkan dapat memberikan sebuah keputusan untuk melihat pola prediksi perilaku konsumen service motor [3]. Selanjutnya pada penelitian untuk menentukan rating untuk memilih buku yang sesuai dengan keinginannya. Dalam penelitian ini menggunakan algoritma klasifikasi Naïve Bayes.Hasil yang diperoleh adalah hasil penentuan rating buku menggunakan metode Naïve dengan hasil $66,98 \%$ akurasi yang didapatkan menunjukan bahwa mayoritas prediksi rating buku cenderung rendah [4].

data yang dibagi 2 yaitu $65 \%$ dari 195 data Pelatihan dan $35 \%$ dari 105 data Pengujian [11]. Penelitian menggunakan Naïve Bayes dalam analisis kepuasan pemakai menggunakan aplikasi windows phone store dengan model evaluasi menggunakan 10 fold crossvalidation. Model yang di proses diperoleh akurasi sebesar $84.50 \%$. Dapat disimpulkan Naïve Bayes merupakan metode yang baik dalam hal klasifikasi [12].

Penelitian untuk prediksi pembelian kendaraan sesuai dengan kebutuhan dana yang dimiliki konsumen menggunakan metode Naïve Bayes. Dari 20 data uji mengenai pembelian mobil menggunakan algoritma Naïve Bayes didapatkan akurasi sebesar 75\% [17]. Penelitian untuk memprediksi masa belajar siswa menggunakan metode Naïve Bayes dan C.45 dengan menggunakan data kelulusan diambil dari siswa angkatan 2011 dan 2012 yang berjumlah 109 [8]. Penelitian pada tahun 2020 mengenai prediksi hasil pertandingan bulu tangkis menggunakan teknik Naïve Bayes yang berdasarkan akurasi, root mean, True positive rate, True negativerate [13]. Pada penelitian mengenai pemetaan kerentanan tanah longsor Penelitian terdahulu yang telah dilakukan tahun 2019 menggunakan model jaringan Naïve Bayes untuk menggunakan metode Naïve Bayes untuk prediksi menentukan peta topografi menggunakan parameter kepuasan pelayanan perekaman e-KTP. Hasil akurasi tanah dan hutan [14]. Selanjutnya penelitian untuk dengan menggunakan data kuesioner dengan 3977 data mengklasifikasi kepuasan pelanggan pada pelayanan adalah sebesar $91.70 \%$ [5]. Penelitian tahun 2019 hotel dengan menggunakan data kuesioner sebanyak menggunakan metode Naïve Bayes untuk mengukur 47.172 ulasan dari 33 hotel [15]. Penelitian tingkat kepuasan pengguna terhadap online menggunakan Naïve Bayes untuk mengklasifikasi systemuniversitas advent indonesia dengan hasil Kanker Payuudara. Dengan hasil prediksi ini akurasi yang didapatkan menggunakan data 150 data memberikan keakuratan maksimum 96,6\% [16].

training. Hasil akurasi yang didapat sebesar 68,6\% [6].

Selanjutnya penelitian terdahulu yang dilakukan pada 2. Metodologi Penelitian

tahun 2018 menggunakan metode Naïve Bayes untuk Penentuan instentif bulanan pegawai pada Edene Sayangku Cafe \& Bakery dengan menggunakan 17 data mengenai pemesanan orderan. Hasil akurasi sebesar $75 \%$ [7]. Selanjutnya penelitian pada tahun 2019 untuk memprediksi tingkat kepuasan mahasiswa terhadap pelayanan akademis dengan data yang digunakan sebanyak 213 data menggunakan kuesioner kepada mahasiswa. Hasil akurasi sebesar 96,71\% dengan nilai precision sebesar $96,15 \%$ dan nilai recall sebesar $98,43 \%$ [8]. Penelitian pada tahun 2020 untuk klasifikasi kepuasan mahasiswa dengan data yang digunakan sebanyak 30 data dengan metode pengambilan data berbentuk kuesioner. Hasil Akurasi yang didapatkan adalah $61 \%$ mahasiwa menjawab puas terhadap sarana dan prasana pembelajaran dan $39 \%$ menjawab tidak puas [9]. Penelitian pada tahun 2019 untuk Analisis sentimen maskapai Citilink pada Twitter dengan metode Naïve Bayes dengan menggunakan

\subsection{Kerangka Kerja Penelitian}

a. Mengidentifikasi Masalah

Pada tahapan ini, penulis akan menganalisa dan mengidentifikasi permasalahan yang akan diteliti. Hal ini bertujuan untuk memahami permasalahan dengan jelas serta dapat mengatasi masalah tersebut dengan baik dan benar.

\section{b. Melakukan Studi Literatur}

Pada tahapan ini, penulis mengadakan eksplorasi terhadap landasan-landasan teori yang didapatkan dari beraneka ragam sumber seperti jurnal, buku, dan juga referensi lainnya untuk melengkapi penelitian ini baik dari segi konsep dan teori yang kemudian memiliki acuan yang baik dan relevan.

\section{c. Pengumpulan Data}

Penulis dalam proses melaksanakan pengumpulan data dengan menggunakan kuesioner secara online 
menggunakan Google Form yang diberikan kepada mahasiswa AMIK Tunas Bangsa angkatan 2020/2021 sebanyak 110 responden. Serta melaksanakan wawancara kepada pihak Lembaga Penjaminan Mutu AMIK Tunas Bangsa tentang proses pendidikan secara daring.

\section{d. Menganalisa Data}

Pada penelitian ini data yang dipergunakan adalah Di mana $D$ adalah data class yang belum diketahui. kumpulan hasil tanggapan dari kuesioner dengan Selanjutnya $K$ adalah hipotesis suatu class yang parameter Komunikasi, Suasana Pembelajaran, spesifik. $P(K \mid D)$ adalah Probabilitas hipotesis $\mathrm{K}$ Penilaian Mahasiswa dan Penyampaian Materi. Seluruh berdasarkan kondisi D.P $(K)$ yaitu probabilitas sesuai data yang sudah didapatkan menggunakan metode dengan hipotesisD. $P(K \mid D)$ merupakan probabilitas kuesioner secara online kemudian akan di analisa dan Dkondisi yang berdasarkan pada hipotesis D. mengklasifikasi menggunakan Microsoft Excel untuk Sedangkan $P(D)$ adalah probailitas K.

mempermudah penulis dalam menganalisa data selanjutnya.

\section{e. Perancangan dan Implementasi}

Pada tahapan ini setelah proses analisis selesai, maka dilakukan tahapan perancangan proses perhitungan menggunakan formula Algoritma Naïve Bayes. Perancangan dilakukan melalui tahapan sebagai berikut:

i. Pengolahan data secara manual menggunakan Software Microsoft Excel dengan Algoritma Naïve Bayes.

ii. Perhitungan secara manual dengan formula Algoritma Naïve Bayes dengan data yang sama.

\section{f. Menguji Hasil}

Pada tahap ini yaitu dilakukan proses menguji hasil dari perhitungan baik itu manual dan menggunakan Tools Rapid Miner 5.3 dengan menerapkan formula dari algoritma Naïve Bayes.

g. Menganalisa Hasil

Analisis dilakukan untuk menganalisa hasil dari perhitungan manual dan pengujian Tools Rapid Miner 5.3 dengan Algoritma Data Mining metode Naïve Bayes serta melihat total akurasi hasil antara perhitungan manual dengan Tools.

h. Pembahasan Hasil Rapid Miner 5.3

Dari hasil pengolahan data yang telah penulis dapatkan dan mengikuti proses kerja penelitian. Penulis akan memberikan hasil dari setiap proses baik itu manual atau menggunakan Tools Rapid Miner 5.3. Di mana proses tersebut akan menghasilkan berupa nilai class precision dan nilai Accuracy pada prediksi tingkat kepuasan mahasiswa dalam pembelajaran secara daring.

\subsection{Model Klasifikasi Naïve Bayes}

Untuk menyelesaikan metode Naïve Bayes dapat dilakukan dengan persamaan-persamaan sebagai berikut [17]:

a. Baca data training

b. Hitung Jumlah dan Probabilitas Prior d. Hitung nilai probabilitas data testing

$P\left(K \mid a 1, \ldots \ldots\right.$, an $=P(D) P\left(a_{1}, \ldots ., a_{n} \mid D\right)(3)$

e. Menghitung Probabilitas Akhir

$P(K \mid D)=P(D \mid K) x P(K \mid D)(4)$

f. Menghitung Nilai Akhir

$C=\arg \max P(D \mid K)$

\subsection{Analisis Data}

Dalam analisis data proses yang dilakukan adalahdengan memberikan kategori A1 - A11 pada setiap pertanyaan yang diajukan pada kuesioner. pada Tabel 1 sampai dengan Tabel 4.

\section{Tabel 1. Tabel Parameter Komunikasi}

\begin{tabular}{|c|c|}
\hline Kat & Pertanyaan \\
\hline A1 & $\begin{array}{l}\text { Dosen memberikan waktu bagi Mahasiwa yang ingin } \\
\text { Mengajukan pertanyaan atau konsultasi mengenai bahan } \\
\text { perkuliahan daring. }\end{array}$ \\
\hline A2 & $\begin{array}{l}\text { Mahasiswa mendapatkan kemudahan dalam } \\
\text { menghubungi dosen untuk bertanya mengenai kesiapan } \\
\text { perkuliahan daring. }\end{array}$ \\
\hline A3 & $\begin{array}{l}\text { Pendekatan dosen dengan mahasiswa berjalan dengan } \\
\text { baik. }\end{array}$ \\
\hline \multicolumn{2}{|r|}{ Tabel 2. Parameter Suasana Pembelajaran } \\
\hline Kat & Pertanyaan \\
\hline A4 & $\begin{array}{l}\text { Saya merasa nyaman ketika mengerjakan evaluasi } \\
\text { pembelajaran (tugas kuis, ujian tengah semester, dan } \\
\text { ujian akhir semester) melalui kuliah daring. }\end{array}$ \\
\hline A5 & $\begin{array}{l}\text { Dalam perkuliahan daring dosen memberikan motivasi } \\
\text { bagi mahasiswa dalam meningkkatkan prestasi } \\
\text { akademik. }\end{array}$ \\
\hline A6 & $\begin{array}{l}\text { Dosen selalu memberikan mahasiswa pertanyaan setiap } \\
\text { selesai proses pembelajaran daring. }\end{array}$ \\
\hline
\end{tabular}
Terdapat 4 parameter dan 11 kategori yang disajikan 
Tabel 3. Parameter Penilaian Mahasiswa

\begin{tabular}{|c|c|}
\hline Kat & Pertanyaan \\
\hline A7 & $\begin{array}{l}\text { Dosen memberikan memberikan penilaian secara } \\
\text { objektif pada masa pandemi } C O V I D-19\end{array}$ \\
\hline A8 & $\begin{array}{l}\text { Dosen memberikan nilai yang sesuai dengan } \\
\text { kemampuan mahasiswa tersebut.s }\end{array}$ \\
\hline & Tabel 4. Parameter Penyampaian Materi \\
\hline Kat & Pertanyaan \\
\hline A9 & $\begin{array}{l}\text { Dosen mengajar sesuai dengan silabus dan rencana } \\
\text { pembelajaran yang sudah sudah ditetapkan perguruan } \\
\text { tinggi. }\end{array}$ \\
\hline A10 & $\begin{array}{l}\text { Tujuan pembelajaran mata kuliah tercapai secara } \\
\text { optimal menggunakan e-learning }\end{array}$ \\
\hline A11 & $\begin{array}{l}\text { Penyampaian materi secara jelas dengan menggunakan } \\
\text { media daring, Baik menggunakan Whatsapp, zoom dan } \\
\text { aplikasi lainnya. }\end{array}$ \\
\hline
\end{tabular}

Setiap parameter terdiri dari 2 atau lebih pertanyaan yang diajukan kepada mahasiswa yang diberikan kepada mahasiswa dan menggunakan skala linker 5 yang terdiri dari S_B, B, C, K, S_K. Kemudian data diolah dan pengujian akurasi dengan Tools Rapid Miner 5.3.

\subsection{Pembagian Data Training dan Testing}

Pada data testing terdapat data sebanyak 80 data Proses menghitung jumlah dan probabilitas dari setiap responden dengan nilai Puas sebanyak 62 dan Tidak kategori berdasarkan dataset pada Tabel 5.

Puas 18 responden. Pada data testing terdapat 30 data uji yang akan diprediksi. Dapat dilihat pada Tabel 5 berikut.

\section{Tabel 5. Data Testing}

\begin{tabular}{|c|c|c|c|c|c|c|c|c|c|c|c|c|}
\hline Res & a1 & $\mathrm{a} 2$ & a3 & $\mathrm{a} 4$ & a5 & a6 & a7 & a8 & a9 & $\mathrm{a} 10$ & a11 & Hasil \\
\hline 1 & $\mathrm{~b}$ & $\mathrm{c}$ & $\mathrm{c}$ & $\mathrm{c}$ & $\mathrm{c}$ & $\mathrm{b}$ & $\mathrm{c}$ & $\mathrm{b}$ & $\mathrm{b}$ & $\mathrm{k}$ & $\mathrm{c}$ & $?$ \\
\hline 2 & $\mathrm{~b}$ & $\mathrm{~b}$ & $\mathrm{~b}$ & $\mathrm{~b}$ & $\mathrm{~b}$ & b & $\mathrm{b}$ & $\mathrm{b}$ & b & $\mathrm{sb}$ & b & $?$ \\
\hline 3 & $\mathrm{~b}$ & $\mathrm{~b}$ & $\mathrm{~b}$ & $\mathrm{~b}$ & $\mathrm{~b}$ & b & c & $\mathrm{c}$ & c & c & $\mathrm{c}$ & $?$ \\
\hline 4 & $\mathrm{sb}$ & $\mathrm{b}$ & $\mathrm{b}$ & $\mathrm{c}$ & $\mathrm{b}$ & b & $\mathrm{b}$ & $\mathrm{b}$ & b & b & b & $?$ \\
\hline 5 & $\mathrm{~b}$ & $\mathrm{~b}$ & $\mathrm{~b}$ & $\mathrm{~b}$ & $\mathrm{~b}$ & b & $\mathrm{b}$ & $\mathrm{b}$ & b & c & $\mathrm{c}$ & $?$ \\
\hline 6 & $\mathrm{~b}$ & $\mathrm{~b}$ & $\mathrm{~b}$ & $\mathrm{~b}$ & $\mathrm{~b}$ & b & $\mathrm{sb}$ & $\mathrm{b}$ & b & c & $\mathrm{c}$ & $?$ \\
\hline 7 & $\mathrm{~b}$ & $\mathrm{~b}$ & $\mathrm{~b}$ & $\mathrm{c}$ & $\mathrm{b}$ & $\mathrm{c}$ & $\mathrm{b}$ & $\mathrm{b}$ & b & $\mathrm{c}$ & $\mathrm{c}$ & $?$ \\
\hline 8 & $\mathrm{~b}$ & $\mathrm{~b}$ & $\mathrm{~b}$ & $\mathrm{~b}$ & $\mathrm{c}$ & b & $\mathrm{b}$ & $b$ & b & c & $\mathrm{c}$ & $?$ \\
\hline 9 & $\mathrm{sb}$ & $\mathrm{b}$ & $\mathrm{b}$ & $\mathrm{b}$ & $\mathrm{b}$ & b & $\mathrm{b}$ & $\mathrm{b}$ & b & b & $\mathrm{b}$ & $?$ \\
\hline 10 & $\mathrm{sb}$ & $\mathrm{b}$ & $\mathrm{b}$ & $\mathrm{b}$ & $\mathrm{b}$ & b & $\mathrm{c}$ & $\mathrm{b}$ & b & b & $\mathrm{b}$ & $?$ \\
\hline 11 & $\mathrm{~b}$ & $\mathrm{~b}$ & $\mathrm{sb}$ & $\mathrm{b}$ & $\mathrm{sb}$ & b & $\mathrm{b}$ & $\mathrm{b}$ & c & $\mathrm{sb}$ & $\mathrm{b}$ & $?$ \\
\hline 12 & $\mathrm{~b}$ & $\mathrm{c}$ & $\mathrm{b}$ & $\mathrm{b}$ & $\mathrm{c}$ & b & $\mathrm{b}$ & $\mathrm{b}$ & b & b & $\mathrm{c}$ & $?$ \\
\hline 13 & $\mathrm{~b}$ & $\mathrm{~b}$ & $\mathrm{~b}$ & $\mathrm{~b}$ & $\mathrm{~b}$ & b & b & $\mathrm{b}$ & b & $\mathrm{sb}$ & $\mathrm{b}$ & $?$ \\
\hline 14 & $\mathrm{~b}$ & $\mathrm{~b}$ & $\mathrm{~b}$ & $\mathrm{~b}$ & $\mathrm{~b}$ & b & b & $\mathrm{b}$ & b & b & $\mathrm{b}$ & $?$ \\
\hline 15 & $\mathrm{~b}$ & $\mathrm{~b}$ & $\mathrm{~b}$ & $\mathrm{~b}$ & $\mathrm{~b}$ & b & $\mathrm{c}$ & $\mathrm{b}$ & c & b & $\mathrm{b}$ & $?$ \\
\hline 16 & sb & $\mathrm{b}$ & $\mathrm{b}$ & $\mathrm{c}$ & $\mathrm{b}$ & b & b & $b$ & b & b & $\mathrm{b}$ & $?$ \\
\hline 17 & $\mathrm{~b}$ & $\mathrm{c}$ & $\mathrm{c}$ & $\mathrm{k}$ & $\mathrm{k}$ & $\mathrm{k}$ & b & $\mathrm{k}$ & c & $\mathrm{k}$ & $\mathrm{k}$ & $?$ \\
\hline 18 & $\mathrm{~b}$ & $\mathrm{c}$ & $\mathrm{b}$ & $\mathrm{k}$ & $\mathrm{k}$ & $\mathrm{k}$ & b & $\mathrm{k}$ & c & $\mathrm{k}$ & $\mathrm{k}$ & $?$ \\
\hline 19 & $\mathrm{~b}$ & $\mathrm{c}$ & $\mathrm{c}$ & sk & $\mathrm{c}$ & $\mathrm{c}$ & c & $\mathrm{k}$ & $\mathrm{k}$ & sk & $\mathrm{c}$ & $?$ \\
\hline 20 & $\mathrm{~b}$ & $\mathrm{~b}$ & $\mathrm{~b}$ & $\mathrm{c}$ & $\mathrm{b}$ & $\mathrm{c}$ & b & $b$ & b & c & $\mathrm{c}$ & $?$ \\
\hline 21 & $\mathrm{~b}$ & $\mathrm{~b}$ & $\mathrm{~b}$ & $\mathrm{c}$ & $\mathrm{c}$ & $\mathrm{c}$ & b & $b$ & b & b & $\mathrm{c}$ & $?$ \\
\hline 22 & $\mathrm{sb}$ & $\mathrm{b}$ & $\mathrm{k}$ & $\mathrm{k}$ & $\mathrm{b}$ & b & b & $\mathrm{b}$ & $\mathrm{c}$ & $\mathrm{b}$ & $\mathrm{b}$ & $?$ \\
\hline 23 & $\mathrm{~b}$ & $\mathrm{~b}$ & $\mathrm{~b}$ & $\mathrm{c}$ & $\mathrm{b}$ & $\mathrm{c}$ & b & b & b & b & $\mathrm{c}$ & $?$ \\
\hline 24 & $\mathrm{~b}$ & $\mathrm{~b}$ & $\mathrm{~b}$ & $\mathrm{c}$ & $\mathrm{b}$ & $\mathrm{c}$ & b & $\mathrm{c}$ & $\mathrm{b}$ & c & $\mathrm{c}$ & $?$ \\
\hline 25 & $\mathrm{~b}$ & $\mathrm{~b}$ & $\mathrm{~b}$ & $\mathrm{k}$ & $\mathrm{c}$ & $\mathrm{c}$ & $\mathrm{b}$ & $\mathrm{b}$ & $\mathrm{b}$ & $\mathrm{c}$ & $\mathrm{c}$ & $?$ \\
\hline 26 & $\mathrm{c}$ & $\mathrm{c}$ & $\mathrm{b}$ & $\mathrm{b}$ & $\mathrm{c}$ & b & $\mathrm{c}$ & $\mathrm{c}$ & $\mathrm{b}$ & $\mathrm{b}$ & $\mathrm{c}$ & $?$ \\
\hline 27 & $\mathrm{~b}$ & $\mathrm{~b}$ & $\mathrm{~b}$ & $\mathrm{~b}$ & $\mathrm{~b}$ & b & $\mathrm{c}$ & $\mathrm{c}$ & $\mathrm{c}$ & $\mathrm{c}$ & $\mathrm{c}$ & $?$ \\
\hline 28 & $\mathrm{~b}$ & $\mathrm{c}$ & $\mathrm{c}$ & $\mathrm{b}$ & $\mathrm{b}$ & $\mathrm{c}$ & $\mathrm{c}$ & $\mathrm{b}$ & $\mathrm{c}$ & $\mathrm{c}$ & $\mathrm{c}$ & $?$ \\
\hline 29 & $\mathrm{~b}$ & $\mathrm{~b}$ & $\mathrm{~b}$ & B & $\mathrm{b}$ & b & $\mathrm{b}$ & $\mathrm{b}$ & $\mathrm{b}$ & b & $\mathrm{b}$ & $?$ \\
\hline 30 & $\mathrm{~b}$ & $\mathrm{c}$ & $\mathrm{c}$ & B & $\mathrm{b}$ & $\mathrm{c}$ & $\mathrm{c}$ & $\mathrm{b}$ & c & $\mathrm{c}$ & $\mathrm{c}$ & $?$ \\
\hline
\end{tabular}

\section{Hasil dan Pembahasan}

\subsection{Alur Proses Algoritma}

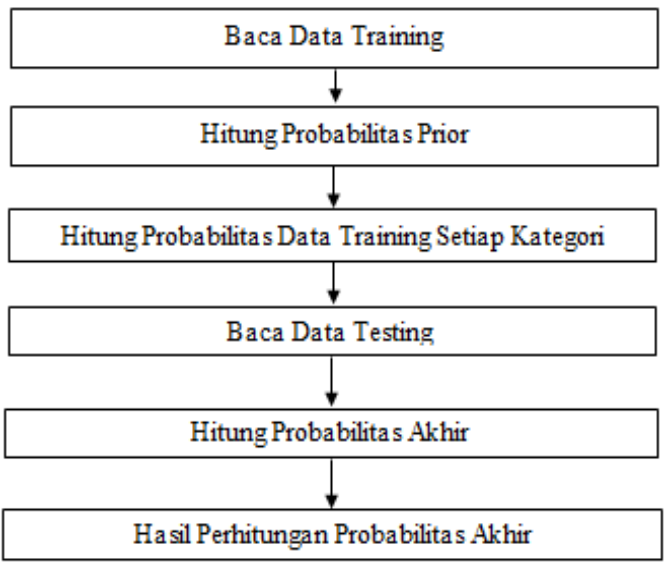

Gambar 1. Alur Proses Algoritma

Berikut penjelasan secara detail serta tahapan proses berdasarkan Gambar 1 di atas.

a. Baca data training

b. Hitung jumlah probabilitas Prior

$$
\begin{aligned}
& P(K \mid P S)=80 / 62=0,775 \\
& P(K \mid T P)=80 / 18=0,225
\end{aligned}
$$

c. Hitung probabilitas pada masing-masing kategori Berikut perhitungan kategori A1 Parameter Komunikasi.

$$
\begin{aligned}
& P(S B \mid P S)=17 / 62=0,2742 \\
& P(S B \mid T P)=1 / 18=0,0556 \\
& P(B \mid P S)=37 / 62=0,5968 \\
& P(B \mid T P)=8 / 18=0,4444 \\
& P(C \mid P S)=8 / 62=0,1290 \\
& P(C \mid T P)=4 / 18=0,2222 \\
& P(K \mid P S)=0 / 62=0 \\
& P(K \mid T P)=3 / 18=0,1667 \\
& P(S K \mid P S)=0 / 62=0 \\
& P(S K \mid T P)=2 / 18=0,1111
\end{aligned}
$$

Tabel 6. Hasil Perhitungan Probabilitas Kategori A1

\begin{tabular}{lcccc}
\hline Kategori : A1 & P & TP & Prob.P & Prob.TP \\
\hline Sangat Baik & 17 & 1 & 0,2742 & 0,0556 \\
Baik & 37 & 8 & 0,5968 & 0,4444 \\
Cukup & 8 & 4 & 0,1290 & 0,2222 \\
Kurang & 0 & 3 & 0 & 0,1667 \\
Sangat Kurang & 0 & 2 & 0 & 0,1111 \\
\hline Jumlah & 62 & 18 & 1 & 1 \\
\hline
\end{tabular}

Selanjutnya perhitungan dengan proses yang sama dilakukan berdasarkan kategori yang digunakan sebanyak 11 katagori. 
d. Baca data testing

Pada tahapan ini Data uji yang digunakan dalam penelitian ini terdiri dari 30 data responden berdasarkan pada Tabel 5.

e. Menghitung probabilitas data testing

Berdasarkan data testing berikut merupakan perhitungan data responden 81 sampai 110 sehinggatotal 30 responden. Proses perhitungan sesuai dengan persaamaan 3 .

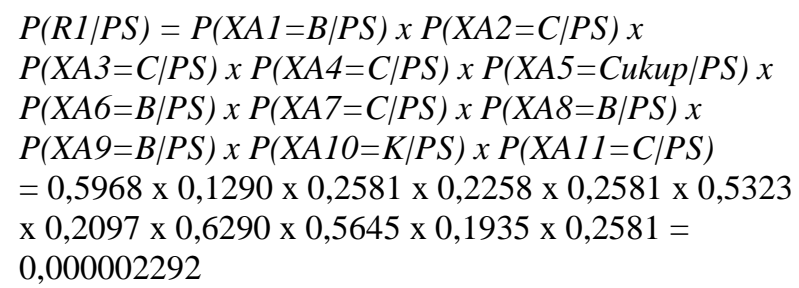

Setelah menghitung data responden 81sampai110 telah diketahui. Selanjutnya perhitungan nillai maksimal masing-masing klasifikasi.

f. Menghitung probabilitas akhir

$$
\begin{aligned}
(\text { Puas } \mid K) & =P(K n \mid D) \times P(P S) \\
& =P(81 \mid D) \times P(P S) \\
& =0,000002292 \times 0,775=0,0000017764132
\end{aligned}
$$

$$
\begin{aligned}
P(\text { Tidak Puas } \mid K) & =P(\text { Kn } \mid D) \times P(T P) \\
= & P(81 \mid D) \times P(T P) \\
& =0,225 \times 0=0
\end{aligned}
$$

g. Perbandingan Nilai Puas dan Tidak Puas

Proses perbandingan nilai puas dan tidak puasproses di lakukan sesuai dengan rumus persamaan 2 .

$$
\begin{aligned}
& R 81=P S>=T P \\
& =0,0000017764132>=0 \\
& =0,0000017764132(P S)
\end{aligned}
$$

Maka proses berlanjut sampai dengan 30 responden. Dapat diketahui data testing dari responden $81-110$ dengan hasil perbandingannilaiterdapat pada Tabel 7 .
Tabel 7. Hasil Perbandingan Nilai

\begin{tabular}{lcll}
\hline No & Puas & \multicolumn{1}{c}{ Tidak Puas } & \multicolumn{1}{c}{ Kelas } \\
\hline 1 & 0,0000017764132 & 0 & Puas \\
2 & 0,0001905762670 & 0 & Puas \\
3 & 0,0000088349794 & 0,0000000823422 & Puas \\
4 & 0,0000746945245 & 0 & Puas \\
5 & 0,0003246854919 & 0,0000001152790 & Puas \\
6 & 0,0001205974684 & 0,0000000329369 & Puas \\
7 & 0,0000755377782 & 0 & Puas \\
8 & 0,0001731655957 & 0,0000004034766 & Puas \\
9 & 0,0001653950185 & 0 & Puas \\
10 & 0,0000614324354 & 0 & Puas \\
11 & 0,0000143256310 & 0 & Puas \\
12 & 0,0000262547614 & 0 & Puas \\
13 & 0,0001905762670 & 0 & Puas \\
14 & 0,0003599773932 & 0 & Puas \\
15 & 0,0000382016825 & 0 & Puas \\
16 & 0,0000746945245 & 0 & Puas \\
17 & 0 & 0,0000013174746 & TidakPuas \\
18 & 0 & 0,0000003293687 & TidakPuas \\
19 & 0 & 0,0000002845745 & TidakPuas \\
20 & 0,0000755377782 & 0 & Puas \\
21 & 0,0000297772111 & 0 & Puas \\
22 & 0,0000005444207 & 0 & Puas \\
23 & 0,0000558322708 & 0 & Puas \\
24 & 0,0000193686611 & 0 & Puas \\
25 & 0,0000287762965 & 0,0000009037876 & Puas \\
26 & 0,0000005406386 & 0 & Puas \\
27 & 0,0000088349794 & 0,0000000823422 & Puas \\
28 & 0,0000020806185 & 0,0000002823160 & Puas \\
29 & 0,0003599773932 & 0,0000000000000 & Puas \\
30 & 0,0000020806185 & 0,0000002823160 & Puas \\
\hline & & & \\
\hline
\end{tabular}

Berdasarkan Tabel 7 dapat dilihat bahwa hasil perhitungan manual dari probabilitas akhir untuk seluruh data testing diperoleh 27 alternatif dengan prediksi Puas dan 3 alternatif dengan prediksi Tidak Puas.

\subsection{Pengujian Naïve Bayes Pada RapidMiner 5.3}

a. Pengujian Probabilitas

Dalam pengujian probabilitas proses sebelumnya adalah import data training sebanyak 80 data. Berikut permodelan validasi terdapat pada Gambar 2.

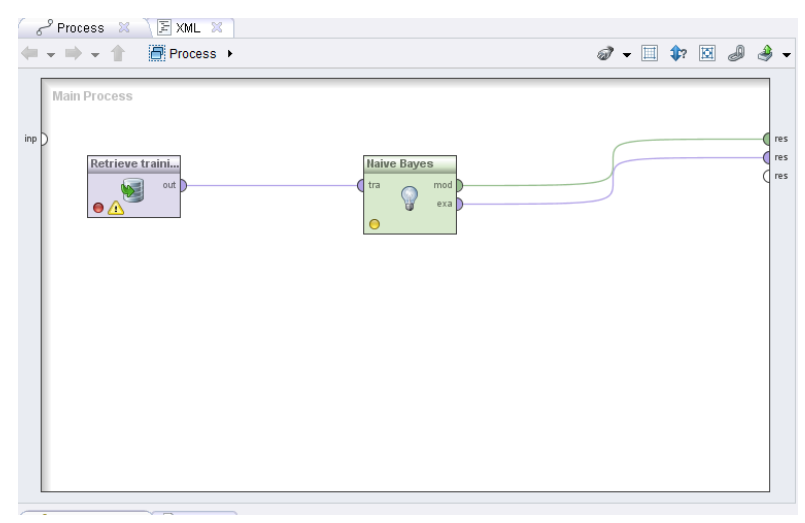

Gambar 2. Pemodelan Data Training

Selanjutnya melihat simple distribution yaitu menentukan banyaknya nilai dari data kelas puas dan tidak puas. Dapat dilihat pada Gambar 3. 


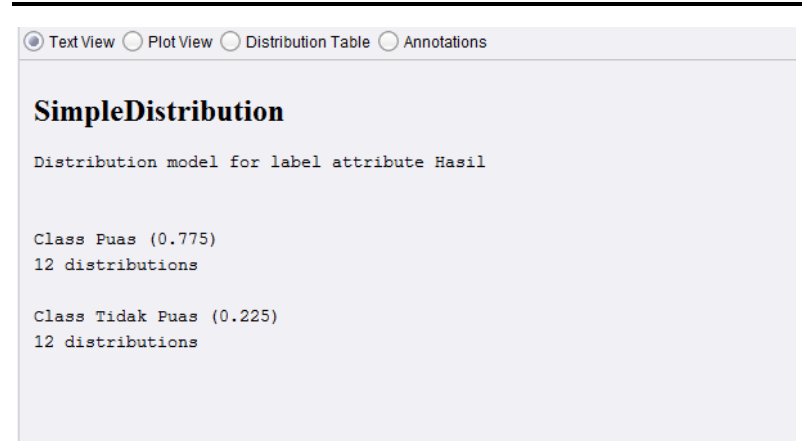

Gambar 3. Pengujian Probabilitas Prior

Berdasarkan Gambar 3 menjelaskan bahwa kelas Tidak Puas memiliki nilai klasifikasi/probabilitas 0,225 sedangkan kelas Puas mendapatkan nilai klasifikasi/probabilitas 0,775.

\section{b. Pemodelan Proses Data Testing}

Dalam proses pemodelan data testing dilakukan dengan berwarna Merah (Tidak Puas) memiliki jumlah node perancangan model berupa model yang terdapat pada yaitu 3, sedangkan pada titik berwarna Merah (Puas) fitur Rapid Miner 5.3 yang dimana proses tersebut akan memiliki hanya 27 node.

berlanjut untuk menentukan berapa besar akurasi dan ketepatan dalam proses prediksi pada data yang penulis sudah di tetapkan.

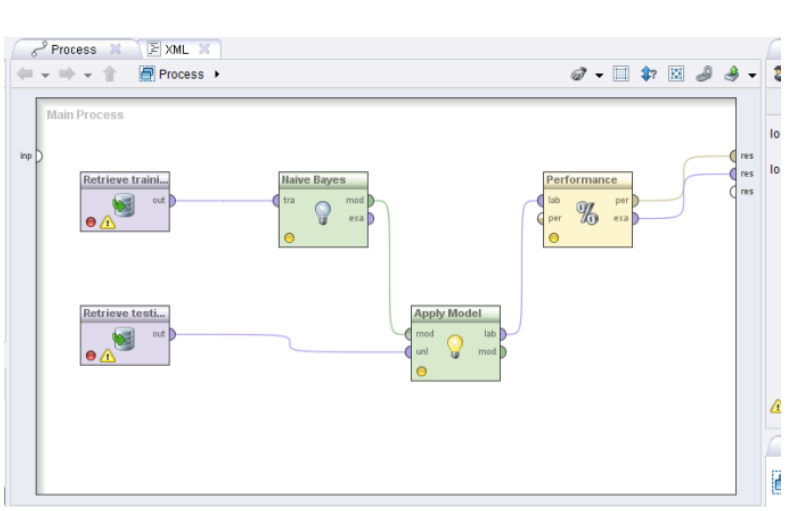

Gambar 4. Pemodelan Proses Data Testing

Pada Gambar 4 merupakan proses pemodelan validasi datatesting yang berfungsi untuk menentukan hasil akhir berupa jumlah puas dan tidak puas serta accuracy dan waktu eksekusi dalam proses prediksi tingkat kepuasan pembelajaran daring.

\section{c. Grafik Klasifikasi Data Training}

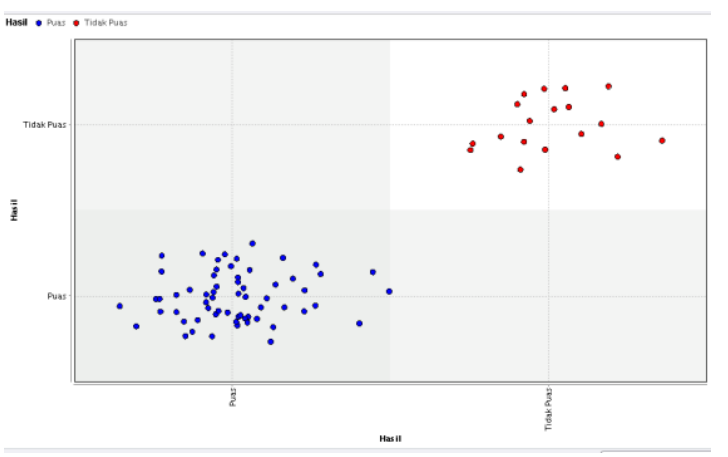

Pada Gambar 5 diketahui bahwa terdapat 62 node dengan nilai Puas dan 18 node menyatakan Tidak Puas.

\section{d. Grafik Klasifikasi Data Testing}

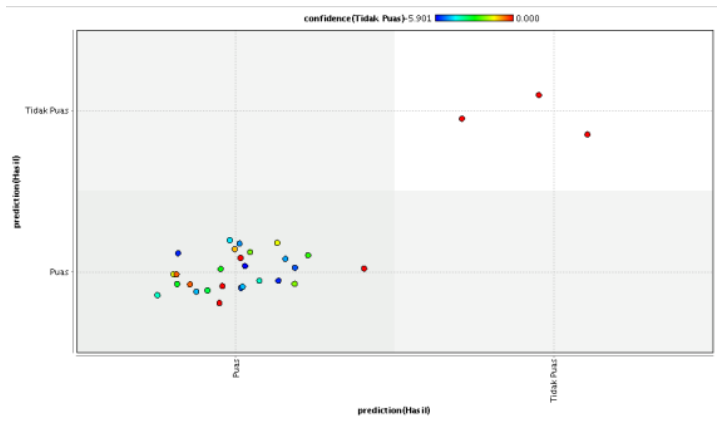

Gambar 6. Grafik Klasifikasi Data Testing

Pada gambar 6dapat diketahui bahwa pada titik e. Accuracy Performance

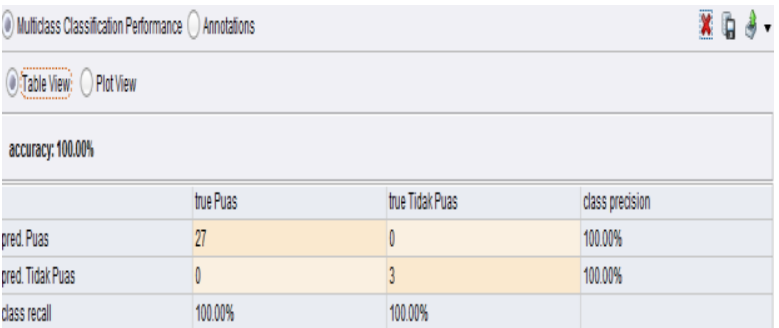

Gambar 7. Accuracy Performance

Berdasarkan gambar 7 dapat dilihat bahwa Jumlah prediksi puas dan kenyataannya benar puas adalah 27 record. Jumlah prediksi Tidak Puas dan kenyataannya benar puas adalah 0 record. Jumlah prediksi Puas dan kenyataannya benar tidak puas adalah 0 record. Jumlah prediksi puas dan kenyataannya benar tidak puas terdapat3 record. Maka total Accuracy yang didapatkanadalah $100 \%$.

\section{Kesimpulan}

Dari hasil pengujian akhir yang dilakukan dari data sampel kuesioner dengan atribut atau indikator komunikasi, suasana pembelajaran, penilaian mahasiswa dan penyampaian materi menggunakan metode Naïve Bayes didapatkan tingkat akurasi sebesar $100 \%$ dengan nilai precision sebesar $100 \%$ dan nilai recall sebesar $100 \%$. Berdasarkan hasil pengujian tersebut maka Model Algoritma Naïve Bayes bisa direkomendasikan untuk prediksi tingkat kepuasan dalam pembelajaran daring pada AMIK Tunas Bangssa Pematangsiantar, karena nilai precision dan recallnya tinggi. 


\section{Daftar Rujukan}

[1] Gustientiedina., Siddik, M., \& Desnelita, Y. (2019). Penerapan Naïve Bayes Untuk Memprediksi Tingkat Kepuasan Mahasiswa Terhadap Pelayanan Akademis. Jurnal Infomedia, 4(2).

[2] Carolina, I., Supriyatna, A., \& Puspitasari, D. (2020). Analisa Tingkat Kepuasan Mahasiswa Terhadap Perkuliahan Daring Pada Era Pandemi COVID-19. Prosiding Seminar Nasional Riset dan Information Science, 2, 342-347.

[3] Simanjuntak, S. F. I., \& Elisa, E. (2020). Analisa Data Mining Menggunakan Metode Bayes Untuk Mengukur Tingkat Kerusakan Mesin. IJTVET: International Journal of Technology Vocational Education and Training, 1(1), 49-54.

[4] Tyas, R. A., Anggraini, M ., Sulasiyah, I. A., \& Aini, Q. (2020).Implementasi Algoritma Naïve Bayes dalam Penentuan Rating Buku. SISTEMASI: Jurnal Sistem Informasi, 9(3). DOI: https://doi.org/10.32520/stmsi.v9i3.915 .

[5] Apandi, T. H., \& Sugianto, C. A. (2019). Algoritma Naïve Bayes untuk Prediksi Kepuasan Pelayanan Perekaman E-KTP. JUITA: Jurnal Informatika, 7(2), 125-128. DOI: https://doi.org/10.30595/juita.v7i2.3608 .

[6] Samuel, Y. T., \& Dewi, K. (2019). Penggunaan Metode Naïve Bayes dalam Mengukur Tingkat Kepuasan Pengguna Terhadap Online System Universitas Advent Indonesia. Jurnal TeIKA, 9(2). DOI: https://doi.org/10.36342/teika.v9i02.2162 .

[7] Siregar, V. M. M. (2018). Sistem Pendukung Keputusan Penentuan Insentif Bulanan Pegawai dengan Menggunakan Metode Naïve Bayes. Jurnal SISTEMASI, 7(2), 87-94.

[8] Gerhana, Y. A., Fallah, I., Zulfikar, W. B., Maylawati, D. S., \& Ramdhani, M. A. (2019). Comparison of Naïve Bayes classifier and C4.5 Algorithms In Predicting Student Study Period. Journal of Physics: Conference Series, 1280(2), 7-19. DOI: https://doi.org/10.1088/1742-6596/1280/2/022022 .

[9] Mariati, E., Lestari, A., \& Widiarty. (2020). Model Klasifikasi Kepuasan Mahasiswa Teknik Terhadap Sarana Pembelajaran
Menggunakan Data Mining. JTI : Jurnal Teknologi Informasi, 14(2). DOI: https://doi.org/10.47111/jti.v14i2.1222 .

10] Yasid, M., \& Janedi, L. (2019). Analisis Sentimen Maskapai Citilink Pada Twitter dengan Metode Naïve Bayes. JIF:Jurnal Ilmiah Informatika, 7(2), 49-54 DOI: https://doi.org/10.33884/jif.v7i02.1329 .

11]Fitriani, A. S. (2019). Penerapan Data Mining Menggunakan Metode Klasifikasi Naïve Bayes untuk Memprediksi Partisipasi Pemilihan Gubernur. JTAM (Jurnal Teori dan Aplikasi Matematika), 3(2), 98-104.

12]Normah, N. (2019). Naïve Bayes Algorithm For Sentiment Analysis Windows Phone Store Application Reviews. Journal Publications \& Informatics Engineering, 3(2). DOI: https://doi.org/10.33395/sinkron.v3i2.242 .

[13] Yang, L., Fu, B., Li, Y., Liu, Y., Huang, W., Feng, S., Xiao, L., Sun, L., Deng, L., Zheng, X., Ye, F., \& Bu, H. (2020). Prediction Model of The Response To Neoadjuvant Chemotherapy in Breast Cancers By a Naïve Bayes Algorithm. Computer Methods and Programs In Biomedicine, 192. DOI: https://doi.org/10.1016/j.cmpb.2020.105458

[14]Lee, S., Lee, M. J., Jung, H. S., \& Lee, S. (2019). Landslide Susceptibility Mapping using Naïve Bayes and Bayesian Network Models in Umyeonsan, Korea.Geocarto International, 35(15). DOI: https://doi.org/10.1080/10106049.2019.1585482 .

[15] Sanchez-Franco, M. J., Navarro-Garcia, A., \& Rondan-Cataluna, F. J. (2018). A Naïve Bayes Strategy for Classifying Customer Satisfaction: A Study Based On Online Reviews of Hospitality Services. Journal of Business Research, 101, 499-506. DOI: https://doi.org/10.1016/j.jbusres.2018.12.051 .

16] Gayathri, B. M., \& Sumathi, C. P. (2016). An Automated Technique using Gaussian Naïve Bayes Classifier to Classify Breast Cancer. International Journal of Computer Applications, 148(6). DOI: http://doi.org/10.5120/ijca2016911146 .

[17]Liantoni, F., \& Nugroho, H. (2015), Klasifikasi Daun Herbal Menggunakan Metode Naïve Bayes Classifier dan K- Nearest Neighbor. Jurnal SimanteC, 